\title{
The Effect of Compensation Studies on Disadvantaged Children's Self Concept Levels and Locus of Control ${ }^{i}$
}

\author{
Ömür Sadioğlu \\ Department of Elementary Education, Faculty of Education, Uludag University, Turkey
}

Copyright $\mathrm{C} 2017$ by authors, all rights reserved. Authors agree that this article remains permanently open access under the terms of the Creative Commons Attribution License 4.0 International License

\begin{abstract}
The aim of this study is to determine the effect of "Bir Umut Ol Benim İçin" (Be My Hope) project which was prepared for the children who were disadvantaged by being influenced from several risk factors as compared to their peers on the self-concepts and locus of controls of the children. The study group consisted of 33 children who were evaluated as disadvantaged by Bursa Police Department Children Branch Office and who were included in "Bir Umut Ol Benim İçin" project. The study examined whether there were significant differences between the pre-test and post-test scores of the locus of control scale and self-concept scale of the children who had participated in the project. It is determined that while "Bir Umut Ol Benim İçin" project has not caused a significant difference between the self-concept scores of the children who have participated in the project, it has caused a significant difference between the locus of control scores of the children. The children have been deemed as internally controlled as a result of their singly planning against their environments which they had to overcome, though their scores have increased a little as a result of them to be under their teacher's control during the studies, their internal controls have been continuing since the scores of the children have been lower than the average.
\end{abstract}

Keywords Compensation Studies, Disadvantaged Children, Locus of Control, Self-concept

\section{Introduction}

The self-concept is one of the factors forming the base of the personality including the views about who he is, his reason for being, what he could do and how he complied with the world [1]. The self-concept which significantly affects the relations and behaviors of the individual towards his environment is regarded as an important reflection of the affective behaviors of the individual [2]. Children form their self-concepts depending on their observations during their growing process, on their experiences, on the feedbacks from their families, peers and teachers about their performance [3]. If the parents give positive feedbacks, award the child and encourage the child for his independence, the child develops an involuntary positive self-concept and becomes internally controlled [4].

The locus of control is the perception of the person about the positive or negative events affecting himself as the results of his own abilities and behaviors or the powers out of him like chance and faith. The person is identified as internally controlled if he perceives the events in his behaviors and abilities; and as externally controlled if he traces them to chance and faith (Strickland, 1977, as cited in Ören, 1991). The internal locus of control is high in people who discipline themselves, however the external locus of control is high in discipline applied by others. The individual having internal control is the individual who can manage himself, take his own decisions and struggle for his desires. On the other hand, the externally controlled individual, as opposed to the internally controlled individual, believes that there were external influences on the events (Ross and Tylor, 1989). When it is considered that the environmental conditions were important in the formation of self-concept and locus of control of an individual, the self-concept and locus of control of the children affected by risk factors are fascinated.

The risk factors are described as effects that would cause the possibility of making a negative case to increase or continuing of a problem (Durlak, 1998). These factors may be classified under four titles as childhood factors, factors arising from family, factors arising from the school and environmental factors. Low birth weight and birth injuries are some of the examples of environmental factors; domestic assault, abuse are examples of the factors arising from the family. School bullying and low school success are the factors arising from the school [8]. Being located mostly in poverty-stricken areas, mostly townships, rural and farm areas make the schools disadvantaged [9]. In addition to this the insufficiency of supporting services, crime inclined environment and social and cultural discrimination are the environmental factors of being disadvantaged [8]. Malinosky-Rummell and Hansen (1993) 
divided the risk factors in children into three as "individual properties, environmental and familial factors". As each of them could be a risk factor singly, more than one factor could also be together [10]. The study emphasized the effects of child, parents and environmental in the surveys rather than a single reason [11]. Due to the stated reasons, the child who cannot find enough family-society and institutional support creates the peer groups in which he could find this support. These groups may sometimes form the main reason of the children being under risk [12.]

The children under risk group are disadvantaged in terms of family and education conditions and they have the risk of being unsuccessful at school or dropping out of school. The disadvantaged child concept is a concept used for the children living in economically, socially, linguistically and educationally negative conditions. Children who are deprived of basic life needs; do not have equal living conditions as their peers and are exposed to negative environmental conditions are described as the disadvantaged children [13]. Meeting the academic and social requirements of these children is very important for reintegrating these children into the society [14].

Two main targets for risk factors are prevention and compensation studies. While prevention studies aim is to prevent the situations which would put the child under risk in the future to occur, the compensation studies are constituted of the activities for overcoming the problems created by the existing risk factors [14.] Kumpfern (1999) lays emphasis on the preventive studies for the children and teenagers under risk (as cited in Gizir, 2007) [15]. It is known that the prevention studies are important for children under risk in terms of assisting them to improve their abilities for having the ability to play along with and cope with the difficulties, for increasing their resistance against traumatic events and for providing social support from their communities [15]. The children who experience risk factors and influenced negatively from them, exhibit behavioral problems and show social disharmony. At this stage, sophisticated and comprehensive compensation studies become significant. The aims of the compensation studies are not only to overcome the behavioral problems of the child but also to provide the child the chance of integrating with the society by removing the negative conditions that cause these behaviors to occur [16].

One of these studies is "Bir Umut Ol Benim İçin" project which was conducted with volunteer teacher candidates and the children under risk between the years 2011-2014 in cooperation with Bursa Police Department Children Branch Office and Uludağ University Faculty of Education in Turkey. The aim of the project is to reintegrate the disadvantaged children who cannot have the equal opportunities with their peers due to the unfavorable environment they have lived in the society by being self and environment respecting, happy, effective and productive individuals by performing academic and social activities with teacher candidates. Also, the teacher act as role models for these children during the Project. Within the context of the project, the studies, social activities and sports activities are organized for the academic and social development of the disadvantaged children with teacher candidates in social and sports centers provided by Bursa Metropolitan Municipality.

\subsection{Aim of the Study}

The aim of this study is to determine the effect of "Bir Umut Ol Benim İçin" project which was prepared for the children who were disadvantaged by being influenced from several risk factors as compared to their peers on the self-concepts and locus of controls of the children. The data obtained is thought to be important as can be used in similar studies and increasing the effectiveness of these studies.

\section{Method}

The explanations about the model of the study, study group, data collection tools and statistical techniques that were used in the analysis of the collected data are included in this section.

\subsection{Research Model}

This research was carried out in conformity with the relational screening model which aims at testing the substantiation of the difference between the related two surveys. It is examined whether there were significant differences between the pre-test and post-test scores of the locus of control scale and self-concept scale of the children who had participated in the project.

\subsection{Participants}

The study group consisted of 33 children who were evaluated as disadvantaged by Bursa Police Department

Children Branch Office. The information about the children who attended the survey is shown in Table 1.

Table 1. Descriptive statistics about the children who attended the project

\begin{tabular}{|c|c|c|c|}
\hline & & $\mathrm{n}$ & $\%$ \\
\hline \multirow{2}{*}{ Gender } & Girl & 5 & 15.2 \\
\hline & Boy & 28 & 84.8 \\
\hline \multicolumn{2}{|c|}{ TOTAL } & 33 & 100 \\
\hline \multirow{4}{*}{ Grade } & 5. & 1 & 3 \\
\hline & 6. & 25 & 75.8 \\
\hline & 7. & 3 & 9.1 \\
\hline & 8. & 4 & 12.1 \\
\hline \multicolumn{2}{|c|}{ TOTAL } & 33 & 100 \\
\hline \multirow{4}{*}{ Age } & 11 & 1 & 3 \\
\hline & 12 & 13 & 39.4 \\
\hline & 13 & 14 & 42.4 \\
\hline & 14 & 5 & 15.2 \\
\hline \multicolumn{2}{|c|}{ TOTAL } & 33 & 100 \\
\hline
\end{tabular}


According to Table 1 the study examined, 33 children, 5 $(15.2 \%)$ were girls and 28 of $(84.8 \%)$ were boys, 13 $(42.2 \%)$ of the children were $13 ; 13(39.4 \%)$ were 12 ; $(15.2 \%)$ were 14 and $1(3 \%)$ were 11 years old. $25(75.8 \%)$ of the children are in 6 . grade, $4(12.1 \%)$ were in 8 . grade, $3(9.1 \%)$ were in 7 . grade and $1(3 \%)$ was in 5 . grade.

\subsection{Data Collection Tools}

\subsubsection{Self-concept Scale of Piers-Harris in Children}

"Self-Concept Scale in Children", developed by Piers-Harris in 1964 and adapted to Turkish by Öner (1996) [17] and Çataklı (1985) [18], has the aim of evaluating the scholastic aptitude, social maturity, independence, accomplishments and self-motivation behaviors of the individuals between the ages of 8-14 [18.] The scale which comprises of 80 items and replied as "Yes" or "No" constituted of sub-scales of "Behavior", "Mental/School Condition", "Physical Appearance", "Apprehension", "Coming Into Vogue" and "Happiness". The answers scores varying between 0 and 80 are obtained. Higher scores indicate the availability of positive self-concept and lower scores show the availability of negative self-concept. The reliability coefficient of the scale varies between .78 and .93 for sub-scales. The reliability coefficient of Turkish form varies between .81 and .89 . The factorial structure of Turkish form shows parallelism with the factorial structure of the original form [17]. In this study, the Cronbach alpha internal consistency coefficient of the scale was found to be at .93 before the beginning of the project and again .93 after the project. Again the reliability study performed for sub-factors of the scale in the pre-test varied between .67 and .83 . and after the post-test varied between .64 and .72 .

\subsubsection{Locus of Control Scale for Children}

Locus of Control Scale for Children which was developed by Nowicki and Strickland in 1973 was adapted into Turkish and confirmed its validity and reliability by Korkut (1986) [20]. It is prepared for children between the ages $8-14$. The scale is consists of 40 items that required marking one of the answers of "Yes" and "No". The external and internal expectations are measured with these questions. 1 point is given in each item to the yes or no option of each statement including the external control. If the child gets a high grade from this scale, it means that the child was externally controlled, meaning that he perceives the events independent of his own behaviors and under the control of external powers, and if the child gets a low grade, it means that the child was internally controlled, meaning that he perceives the events under his own control. In this study, coefficient of internal consistence of Cronbach's alpha was found to be at .61 in pretest and 70 in posttest.

\subsection{Analysis of the Data}

The scores obtained from scales are analyzed with related group $t$ test and the provided data are given in the findings section and the results were achieved after they have been interpreted in later sections.

\section{Results}

Table 2. The Minimum and Maximum Values of Locus of Control and Self-concept Scores of Children, their Standard Deviations and Averages

\begin{tabular}{|c|c|c|c|c|c|c|}
\hline & Groups & $\mathrm{N}$ & Min & Max & $\overline{\mathrm{x}}$ & ss \\
\hline Locus of & Pre-test & 31 & 5 & 22 & 11.97 & 4.086 \\
\hline control & Post-test & 31 & 1 & 24 & 14.67 & 5.140 \\
\hline \multirow{2}{*}{ Self-Concept } & Pre-test & 32 & 16 & 77 & 57.90 & 14.445 \\
\hline & Post-test & 32 & 13 & 77 & 56.65 & 13.700 \\
\hline
\end{tabular}

According to Table 2 the average of the locus of control pre-test score of the students was 11.97, while the average of the post -test score was 14.67. On the other hand, the average of self-concept pre-test score was 57.90 and the average of the post-test score was 56.65. When it is considered that the highest score that would be got from the locus of control scale is 40 , it was established that both the pre-test and post -test scores of the students from the locus of control have been meaning that they have been internally controlled. The highest score that would be taken from self-concept scale is 80 . Accordingly, it is found that the pre-test and post-test scores of the students were over the average. 
Table 3. The T Test Results of The Locus of Control and Self-Concept Pre-Test and Post-Test Scores of the Children

\begin{tabular}{|c|c|c|c|c|c|c|c|}
\hline & Groups & $\mathrm{N}$ & $\bar{x}$ & ss & $\mathrm{t}$ & $\mathrm{Sd}$ & $\mathrm{p}$ \\
\hline \multirow{2}{*}{ Locus of control } & Pre-test & 31 & 11.97 & 4.086 & \multirow{2}{*}{-2.523} & \multirow{2}{*}{30} & \multirow{2}{*}{$.017^{*}$} \\
\hline & Post-test & 31 & 14.67 & 5.140 & & & \\
\hline \multirow{2}{*}{ Self-concept } & Pre-test & 32 & 57.90 & 14.445 & \multirow{2}{*}{.763} & \multirow{2}{*}{31} & \multirow{2}{*}{.451} \\
\hline & Post-test & 32 & 56.65 & 13.700 & & & \\
\hline
\end{tabular}

When $\mathrm{t}$ test results of the locus of control and self-concept pre-test and post-test scores of the children who participated in "Bir Umut Ol Benim İçin" project are examined in Table 3, it indicates that the project have caused a significant difference on the locus of control of the children $(t=-2.523, p<.05)$. Even though the locus of control scores of the children have increased in the post-test, it could be said that the children have been internally controlled since their averages of the post-test had been lower than the average that would be taken from the test. Both the self-concept pre-test and post-test scores of the children were above average. Consequently, it can be concluded that the project have not caused a significant difference on the self-concept of the children $(t=.763, \mathrm{p}>.05)$.

Table 4. The $\mathrm{T}$ Test Results of the Sub-Factors of the Self-Concept Pre-Test and Post-Test Scores of the Children

\begin{tabular}{|c|c|c|c|c|c|c|c|}
\hline Sub-factors of the self-concept & Groups & $\mathrm{N}$ & $\overline{\mathrm{x}}$ & ss & $\mathrm{t}$ & $\mathrm{Sd}$ & $\mathrm{p}$ \\
\hline \multirow{2}{*}{ Factor I (Happiness, Satisfaction) } & Pre-test & 32 & 9.87 & 2.209 & \multirow{2}{*}{-.199} & \multirow{2}{*}{31} & \multirow{2}{*}{.844} \\
\hline & Post-test & 32 & 9.93 & 2.513 & & & \\
\hline \multirow{2}{*}{ Factor II (Anxiety) } & Pre-test & 32 & 7.87 & 2.791 & \multirow{2}{*}{.832} & \multirow{2}{*}{31} & \multirow{2}{*}{.412} \\
\hline & Post-test & 32 & 7.50 & 2.759 & & & \\
\hline \multirow{2}{*}{$\begin{array}{c}\text { Factor III (Popularity, Social Admiration } \\
\text { or Coming Into Vogue) }\end{array}$} & Pre-test & 32 & 8.93 & 2.675 & \multirow{2}{*}{1.198} & \multirow{2}{*}{31} & \multirow{2}{*}{.240} \\
\hline & Post-test & 32 & 8.46 & 2.368 & & & \\
\hline \multirow{2}{*}{ Factor IV (Behavior and Conformity) } & Pre-test & 32 & 11.43 & 3.491 & \multirow{2}{*}{1.052} & \multirow{2}{*}{31} & \multirow{2}{*}{.301} \\
\hline & Post-test & 32 & 10.87 & 3.289 & & & \\
\hline \multirow{2}{*}{ Factor V (Physical Appearance) } & Pre-test & 32 & 7.15 & 2.604 & \multirow{2}{*}{-1.690} & \multirow{2}{*}{31} & \multirow{2}{*}{.101} \\
\hline & Post-test & 32 & 7.68 & 2.191 & & & \\
\hline \multirow{2}{*}{ Factor VI (Mental and School Situation) } & Pre-test & 32 & 5.09 & 1.837 & \multirow{2}{*}{2.273} & \multirow{2}{*}{31} & \multirow{2}{*}{$.030^{*}$} \\
\hline & Post-test & 32 & 4.50 & 1.846 & & & \\
\hline
\end{tabular}

Table 4 shows the averages of pre-test and post-test scores that the children attained from self-concept scale sub-factors and the $t$ test results. Pursuant to this, while a significant difference have not been seen in the averages of pre-test and post-test scores of the children in the sub-factors "Happiness, Satisfaciton" $(\mathrm{t}=-.199, \mathrm{p}>.05)$, "Anxiety" ( $\mathrm{t}=.832, \mathrm{p}>.05)$, "Popularity, Social Admiration or Coming Into Vogue" $(\mathrm{t}=1.198, \mathrm{p}>.05)$, "Behavior and Conformity" ( $\mathrm{t}=1.052, \mathrm{p}>.05)$, "Physical Appearance", a difference is identified between the averages of the pre-test and post-test scores in sub-factor "Mental and School Situation" $(\mathrm{t}=2.273, \mathrm{p}<.05)$ in favor of the pre-test. This is associated with the passage of students into an upper class when the post-test was applied.

\section{Conclusions}

It is has been concluded that while "Bir Umut Ol Benim İçin" project has not caused a significant difference between the self-concept scores of the children who have participated in the project, it has caused a significant difference between the locus of control scores of the children. Even though there have been an increase in the locus of control posttest scores of the children, it might be said that the children have been internally controlled since the score obtained had been lower than the average. In the study carried out by Başal, Taner Derman and Feymi (2010) [21], it is specified that the locus of control scores of the children who were evaluated as under risk since they had been employed in the streets have been low and they have been internally controlled. Dönmez (1983) [22], have concluded in his study that the environment, in which it is experienced, influences internal control. According to Lefcourt (1976) the external locus of control prevents the effort that would be shown in order to overcome this. That is to say, the internal locus of control is a desired situation for the individual [22]. Daniels and Stevens (2004) [23] stated that the children have been deemed as internally controlled as a result of planning individually against their environments which they had to overcome, though their scores have increased a little as a result of being under their teacher's control during the studies, their internal controls have been continuing since the scores of the children have been lower than the average. 
Additionally, the average grades of the children that were attained from pre-test and post -test showed that they have had a positive self-concept. Önder and Gülay (2008) [24]. had identified a positive relationship between the self-concepts and psychological strength of the children in the study they had carried out with the children of elementary education eighth classes. Psychological strength, which is a general concept dealing with how a child has coped with stress and how he has escaped from trauma (Murphy, 1987, as cited in Gizir 2007 [15]), recalls to the mind that the children who have attended the project have been trying to overcome the risk factors with the methods they had held up as an example from their own environmental conditions (violence, bullying, smoking among others). Thereby, in the said environmental conditions, it could be evaluated as a normal result of the self-concepts of the children who have been accepted in their environment to be positive.

In accordance with the findings obtained in the study, it is thought that the qualitatively figured studies for the self-concepts and locus of controls of the disadvantaged children have made significant contributions to the field. Additionally, it is thought to be important to undertake studies in which the psychological strengths of the children would be determined. One another suggestion is that the necessity to carry out studies in which teachers and families are also involved by considering the importance of the effect of the environment to these studies. The increase in the number of prevention and compensation studies for the children who face various risk factors would facilitate more children to be reintegrated into the society.

\section{REFERENCES}

[1] Öner, U. Benlik gelişimine ilişkin kuramlar, In B. Onur (eds). Ergenlik psikolojisi (2 nd ed). Ankara: Hacettepe Taş Kitapçılık, 1987

[2] Yildız G \& Fer S. Öz kavram envanterinin geçerlik ve güvenirlik çalışması. Yüzüncü Yll Üniversitesi Ĕ̌itim Fakültesi Dergisi, 5 (2): 209-232. 2008.

[3] Hay I, Ashman AF \& Van Kraayenoord CE. Educational characteristics of students with high or low self - concept. Psychology in the Schools, 1998, 35 (4): 391-400.

[4] Gordon T. Çocukta dış disiplin mi? İç disiplin mi? İstanbul: Sistem Yayinc1lık, 2000

[5] Ören N. Denetim odağı ve kendini kabul arasındaki ilişkiler. Psikolojik Danışma ve Rehberlik Dergisi, 1991, 1(2): 20-28.

[6] Ross MW \& Taylor MC. The relationship between locus of control and academic level and sex of secondary school students. Contemporaray Educational Psychology, 1989, 14(4): 315-322.

[7] Durlak JA. Common risk and protective factors in successful prevention programs. American Journal of Orthopsychiatry, 1998, 68(4): 512-520.

[8] www.community.nsw.gov.au. Risk, protection and resilience. Avaliable at http://www.community.nsw.gov.au /docswr/assets/main/

documents/researchnotes_resilience.pdf. 2007. Accessed 24 August 2015.

[9] Xaba M \& Malindi M. Entrepreneurial orientation and practice: three case examples of historically disadvantaged primary schools. South African Journal of Education, 2010, 30 (1): 75-89.

[10] Malinosky-Rummell R \& Hansen DJ. Long-term consequences of childhood physical abuse. Psychological Bulletin, 1993, 114 (1): 68.

[11] Glaser D. Emotional abuse and neglect (psychological maltreatment): a conceptual framework. Child Abuse and Neglect, 2002, 26: 697-714.

[12] Cevher DM. Suça sürüklenen çocuklar. In Adem Solak (eds), Okullarda şiddet ve çocuk suçluluğu. Ankara: Hegem Yayınları, 2007.

[13] Dash M. Education of exceptional children. New Delhi: Atlantic publishers and distributors (p) LTD. 2007. Kırcaali-İftar G. Özel gereksinimi olan diğer öğrenciler. In S. Eripek (eds). İlköğretimde kaynaştırma. Eskişehir: Anadolu Üniversitesi Yayınları. 2007.

[14] Gizir CA. Psikolojik sağlamlık, risk faktörleri ve koruyucu faktörler üzerine bir derleme çalışması. Türk Psikolojik Danışma ve Rehberlik Dergisi, 2007, 28:113-128.

[15] Sarpdağ M. Çocuk suçluluğu ve polis. Ankara: Ahsen Matbaacilık, 2005.

[16] Öner N. Piers- Harris çocuklarda öz-kavramı ölçeği el kitabı. Ankara: Türk Psikologlar Derneği, 1996.

[17] Çataklı M. Transliteral equivalence and reliabilty of the Turkish version of the Piers-Harris children's self-concept scale. Yüksek lisans tezi. İstanbul: Boğaziçi Üniversitesi, 1985.

[18] Öner N. Türkiye'de kullanılan psikolojik testlerden örnekler bir başvuru kaynağı (2nd ed). İstanbul: Boğaziçi Üniversitesi, 2008.

[19] Korkut F. İlkokul öğrencilerinin kendilerine ve ailelerine ilişkin bazı değişkenlerin denetim odakları üzerine etkisi. Bilim uzmanlığı tezi. Ankara: Hacettepe Üniversitesi, 1986.

[20] Başal HA, Taner Derman M \& Feymi P. Sokakta çalıştırılan çocukların benlik saygısı, denetim odağı ve umutsuzluk düzeyleri. e-Journal of New World Sciences Academy (NWSA), 2010, 5 (1): 89-106.

[21] Dönmez A. Denetim odağı ve çevre büyüklüğü, Ankara Üniversitesi Eğitim Bilimleri Fakültesi Yayınlarl, 1983, 16(1): 37-47.

[22] Daniels RL \& Stevens JP. The interaction between the internal- external locus of control and two methods of college instruction. American Educational Research Journal, 2004, 13(2): 103-113.

[23] Önder A \& Gülay H. İlköğretim 8. sınıf öğrencilerinin 
psikolojik sağlamlığının çeşitli değişkenler açısından incelenmesi. Dokuz Eylül Üniversitesi Buca Ĕgitim
Fakültesi Dergisi, 2008, 23: 192-197.

${ }^{\mathrm{i}}$ This paper has been granted by the Uludağ University Research Projects Coordination Office. Project Grant Number: ÜSIIP(E)-2012/6 and title Dezavantajlı Çocukları Topluma Kazandırma Çalışmaları: "Bir Umut Ol Benim İçin". And it is an extended form of the paper presented at the 3rd International Symposium "New Issues on Teacher Education" held in University of Thessaly, Volos, Greece on September 11 - 13, 2015. 